\title{
Microbial evaluation of the handling of antineoplastic agents at a reference cancer treatment hospital in Pará State, Brazil
}

Avaliação microbiológica do processo de manipulação de antineoplásicos em um hospital de referência no tratamento de câncer no Estado do Pará, Brasil

Evaluación microbiológica del proceso de manipulación de antineoplásicos en un hospital de referencia en el tratamiento de cáncer en el Estado de Pará, Brasil

Jackeline Sousa Carréra

Programa de Residência Multiprofissional em Saúde, Hospital Universitário João de Barros Barreto, Universidade Federal do Pará, Belém, Pará, Brasil

Daisy Esther Batista do Nascimento

Programa de Residência Multiprofissional em Saúde, Hospital

Universitário João de Barros Barreto, Universidade Federal do Pará, Belém, Pará, Brasil

\section{Celso da Silva Mascarenhas}

Farmácia Satélite da Quimioterapia, Hospital Ophir Loyola, Belém, Pará, Brasil
Lúcia Carla Vasconcelos de Mendonça

Faculdade de Farmácia, Universidade Federal do Pará, Belém, Pará, Brasil

Marta Chagas Monteiro

Faculdade de Farmácia, Universidade Federal do Pará, Belém, Pará, Brasil

Cristiane do Socorro Ferraz Maia

Faculdade de Farmácia, Universidade Federal do Pará, Belém, Pará, Brasil

\begin{abstract}
The Agência Nacional de Vigilância Sanitária RDC 220/04 sets minimum requirements for operating an antineoplastic therapy service, which emphasizes the importance of a quality assurance system that incorporates the best practices for the preparation of antineoplastic therapy. According to pharmacy protocols, pharmaceutical products must be of a quality that complies with specifications determined by official codes. The microbiological quality of the environment for the preparation of these medicines is a critical factor in achieving efficiency and safety. Patient safety depends on the sterility of the product because these patients are usually immunocompromised. The aim of this study was to assess the microbiological quality of the process of handling anti-cancer drugs at a reference cancer treatment hospital in Pará State, Brazil. Material was collected by surface swab and spontaneous sedimentation from the biological safety cabinet (BSC), the handlers' gloves and the air conditioning system. The bacteria and fungi were identified using standard biochemical procedures and microculture. We isolated 31 colony forming units: 22 were from samples from the BSC, six from the air conditioning system and three from the handler's glove. The majority of the microorganisms identified in the BSC samples were Staphylococcus and Bacillus sp. Staphylococcus and Klebsiella sp were found on the handlers' gloves and in the air conditioning system. These results showed microbiological contamination of processes involved in antineoplastic preparations. A continuous monitoring of microbiological quality of the processes, equipment and the environment is necessary as well as a validation of asepsis and restructuring of the physical space to conform to the RDC 50/02 and 220/04.
\end{abstract}

Keywords: Antineoplastic Agents; Drug Contamination; Good Manipulation Practices; Staphylococcus; Bacillus; Klebsiella.

\section{INTRODUCTION}

Anticancer drug therapy, or chemotherapy, has become one of the most important and promising anti-cancer procedures and involves the use of chemical agents,

\footnotetext{
Correspondence / Correspondência / Correspondencia:

Cristiane do Socorro Ferraz Maia

Faculdade de Farmácia, Universidade Federal do Pará

Av. Augusto Corrêa, n01, Bairro: Guamá

CEP: 66075-110 Belém-Pará-Brasil

Tel.: + 55 (91) $3201-7202$

E-mail: crismaia@ufpa.br
}

individually or in combination, that are administered orally, intravenously, intra-arterially, intracavitarially or intramuscularly for the treatment of malignancies. This therapy is a form of systemic treatment and differs from older therapies and localized treatment options, such as surgery and radiotherapy'.

The preparation and handling of sterile products, such as chemotherapy agents, require care and should be performed by qualified personnel who are trained specifically for aseptic procedures to ensure consistency in obtaining sterile products of acceptable quality ${ }^{2}$. Microbial contamination can compromise the performance of the product by causing a breach of the stability of the 
formulation or by modification of physical and organoleptic characteristics, leading to the inactivation of the active ingredients and the excipients of formulation ${ }^{3}$.

Aseptic technique for the preparation of intravenous solutions is of extreme importance for patient survival because once contaminated, the therapy can cause systemic infections after it is injected into the bloodstream ${ }^{4}$. Because these patients are typically immunosuppressed and most chemotherapeutic drugs do not have antimicrobial activity (especially against Pseudomonas aeruginosa and multi-resistant Staphylococcus aureus), patient safety depends on the sterility of the product ${ }^{5}$.

Thus, studies that evaluate the processes of preparing the sterile product are extremely important because they allow the evaluation of possible microbial contaminations during all stages. Microbial growth is evidence that the technique and/or physical structure of the environment does not fit the Technical Regulations established by the Agência Nacional de Vigilância Sanitária (Anvisa) RDC 220/04, which sets the minimum requirements for the operation of the antineoplastic therapy service (ATS). The regulations demand that a quality assurance system should be incorporated into the good practices for preparation of antineoplastic therapy (GPPAT) and an effectively documented and monitored quality control. Therefore, the aim of this study was to evaluate the microbiological quality of the handling stage of the ATS at a reference hospital for cancer treatment in the City of Belém, Pará State, Brazil, to comply with the GPPAT and thus ensure product and service quality and to correct any non-compliance with the current legislation ${ }^{6,7}$.

\section{MATERIALS AND METHODS}

\section{SAMPLE AND STUDY SITE}

The samples were collected over three days and were chosen at random during the preparation of chemotherapeutic agents in the ATS handling room at a reference hospital in oncology in the City of Belém.

The study material consisted of 31 colonies that were collected as follows: one plate was placed within the biological safety cabinet (BSC) for $6 \mathrm{~h}$ (sedimentation method); one plate contained a sample that was collected by swabbing the surface of the BSC; two plates each contained swab sample from the gloves of the three handlers, named A, B and C, collected at the beginning of the testing period and at the end of the testing period and one plate was placed in front of the air conditioning system for $5 \mathrm{~min}$.

\section{PRINCIPLE OF THE TECHNIQUES}

This was an observational, descriptive, prospective study in which two air sampling techniques were used for microbiological environment control: the sedimentation plate method ${ }^{8,9}$ and the surface contact method ${ }^{10}$.

The surface swab method was used to collect material from contact surfaces and from the handlers' gloves. The sedimentation method was used to collect samples from the air conditioning system and from the BSC and consisted of exposing a $90-\mathrm{mm}$ diameter petri plate with $20 \mathrm{~mL}$ of selective or non-selective medium (the nutrient agar) to the air in that environment for $6 \mathrm{~h}$. The colonies were deposited by gravity and then counted. The plates were identified and packed in thermic styrofoam boxes under aseptic conditions and subsequently transported to the microbiology laboratory, where they were incubated at $37^{\circ}$ $\mathrm{C}$ for 24 to $48 \mathrm{~h}$; the evaluation was performed by determining the number of colony forming units (CFU) according to Pasquarella et al ${ }^{8}$.

Subsequently, the colonies were identified based on their Gram stain characteristics and were cultivated at $37^{\circ}$ $C$ in MacConkey Agar medium (HIMEDIA) or Mannitol Agar Salt (HIMEDIA) (in two plates of each medium). The colonies that presented themselves as Gram-positive cocci grouped in clusters were subjected to biochemical identification tests for catalase, oxidase and coagulase activity ". The Gram-negative organisms were identified based on their growth on MacConkey Agar and underwent biochemical tests, such as citrate, urea, H2S, indole, motility, lysine decarboxylase and oxidase/glucose and sucrose fermentation, for identification of enterobacteria and non-fermenting bacilli ${ }^{12}$. In the case of fungal growth in Sabouraud medium, growth was evaluated on a slide using cotton blue dye or clarified with $\mathrm{KOH}$ and microculture.

The microculture technique involves placing a small sample of the culture medium containing the fungus on a slide for microscopy. A coverslip is laid over the sample and the slide is placed in a moist room. The fungus grows at the bottom of the coverslip and develops fructifications that can be analyzed directly through the microscope without being destroyed by manipulation". The recommended limits for microbiological monitoring of clean rooms in the operation are determined based on the Pharmaceutical Inspection Convention (PIC) in which the aseptic preparation of solutions is described in group $A^{10,13}$ (Table 1).

Table 1 - Recommended limits for microbial contamination according to the Guide to Good Manufacturing Practice for Medicinal Products of the PIC

\begin{tabular}{ccccc}
\hline \multicolumn{5}{c}{ Recommended limits for microbial contamination } \\
\hline Grade & $\begin{array}{c}\text { Air } \\
\text { sample } \\
\text { CFU/m }\end{array}$ & $\begin{array}{c}\text { Settle plates } \\
\text { (diam. 90 mm). } \\
\text { CFU/4 h }\end{array}$ & $\begin{array}{c}\text { Contact Plates } \\
\text { (diam. 55 mm) } \\
\text { CFU/plate }\end{array}$ & $\begin{array}{c}\text { Glove print } \\
5 \text { fingers } \\
\text { CFU/glove }\end{array}$ \\
\hline A & $<1$ & $<1$ & $<1$ & $<1$ \\
B & 10 & 5 & 5 & 5 \\
C & 100 & 25 & 25 & - \\
D & 200 & 100 & 50 & - \\
\hline
\end{tabular}

Conventional sign used: - Numerical data not equal to zero due to rounding.

Source: Pharmaceutical Inspection Convention ${ }^{10}$ and European Good Manufacturing Practices ${ }^{13}$. 


\section{ETHICS}

The project (protocol 1329/10) was approved by the Ethics in Research Committee of the Hospital Universitário João de Barros Barreto of the Universidade Federal do Pará (HUJBB/UFPA) (CAAE - 3076.0.000.071-10), and the procedures comply with Resolution 196/96 of the Conselho Nacional de Saúde.

\section{RESULTS}

A total of 31 CFU's were isolated from the analyzed sources: 22 (71\%) were obtained from the BSC, three (10\%) were obtained from the handlers' gloves and six (19\%) were obtained from the air conditioning system (Figure 1).

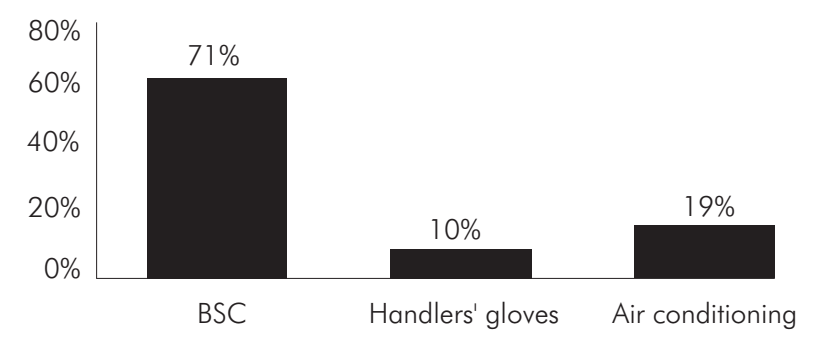

Figure 1 - Percentage distribution of CFU's according to the sources: BSC, handlers' gloves and air conditioning

The qualitative analysis of the colonies demonstrated that potentially pathogenic microorganisms had been isolated from all samples from the three analyzed sources. Bacteria from the coagulase-negative staphylococcus group were the most commonly detected microorganisms in the analyzed samples (23 of 31 colonies or $74.19 \%$ ).

Overall, 18 (82\%) of the 22 CFU's isolated from the BSC were obtained with the sedimentation method and four (18\%) were obtained with the surface swab method. The results showed a higher frequency of Gram-positive bacteria, and the most common microorganism was coagulasenegative staphylococcus (73\%), followed by Gram-positive bacillus (13.5\%). Only one Gram-negative bacterium was isolated: a non-fermenting Gram-negative bacillus (4.5\%) ${ }^{14}$. Furthermore, filamentous fungi of the genus Curvularia $\mathrm{sp}$ were found at a frequency of $9 \%$ (Table 2).

Table 2 - Value of microorganisms and the number of CFU's by two collection methods in BSC

\begin{tabular}{lccccc}
\hline \multicolumn{1}{c}{$\begin{array}{c}\text { Microorganisms } \\
\text { isolated }\end{array}$} & $\begin{array}{c}\text { Spontaneous } \\
\text { sedimentation } \\
\text { (CFU) }\end{array}$ & $\begin{array}{c}\text { Collection } \\
\text { surface by } \\
\text { swab (CFU) }\end{array}$ & \multicolumn{2}{c}{ CFU } & $\%$ \\
\hline $\begin{array}{l}\text { Coagulase-negative } \\
\text { staphylococci }\end{array}$ & 14 & 2 & 16 & 73 \\
$\begin{array}{l}\text { Gram-positive bacilli } \\
\text { Non-fermenting }\end{array}$ & 2 & 1 & 3 & 13.5 \\
$\begin{array}{l}\text { Gram-negative bacilli } \\
\text { Filamentous fungi, }\end{array}$ & 1 & - & 1 & 4.5 \\
genus Curvularia sp & 1 & 1 & 2 & 9 \\
\hline Total & 18 & 4 & 22 & 100 \\
\hline
\end{tabular}

N: Number; \%: Percentage; Conventional sign used: - Numerical data not equal to zero due to rounding.
Glove samples were obtained at two timepoints: before and after the handling process. At the beginning of manipulation, there was no growth from any glove samples, which demonstrated that the gloves were sterile. However, contamination was observed in samples collected during the second day of the collection.

Among the three technicians' gloves that were analyzed, only the samples collected from the handler B's glove showed microbiological contamination with coagulasenegative bacteria (two CFU's, 67\%) and Klebsiella sp (one CFU, 33\%).

In the manipulation room air conditioning system samples, five (83\%) CFU's of coagulase-negative staphylococcus and one (17\%) CFU of Klebsiella sp were found. Moreover, variations in room temperature were observed, and the air conditioner cleaning filter was absent from the register.

\section{DISCUSSION}

Air microbes are difficult to quantify, and four main methods can be used: the counting of $\mathrm{CFU} / \mathrm{m}^{3}$ in air, the counting of CFU on plates, the measurement of chemical components of microbial cells $/ \mathrm{m}^{3}$ in air; and counting under the microscope. Air samples can be collected in two ways. Active air sampling involves collecting a known volume of air in a nutrient medium using differentiated and specific techniques, and the passive method consists of the use of petri plates containing solid nutrient medium that are left exposed to air for a given time period; this is considered a qualitative method ${ }^{8}$.

In this study, the analysis revealed a high rate of contamination in the studied samples, mainly in the 2BII class cabinet and on the technicians' gloves, where no type of microbial growth should occur ${ }^{15}$.

The main microorganisms isolated from the samples from the BSC, which were coagulase-negative staphylococci (73\%) and Gram-positive bacilli (13.5\%), are widely distributed in the environment and are found as part of the normal flora of the skin and mucous membranes of humans and animals. Recent studies of microbiological monitoring in non-classified environments using the same methodology detected the presence of these microorganisms ${ }^{9}$.

Although these microorganisms are considered environmental contaminants, they may behave as opportunistic pathogens and are capable of producing disease in immunocompromised individuals, which is important because most cancer patients are immunocompromised ${ }^{16}$. Coagulase-negative staphylococci, in particular, have been highlighted as an important agent of human diseases, such as bacteremia, endocarditis and osteomyelitis, in addition to the emergence of resistance to commonly-used antimicrobials $^{11}$.

The two methods of collection from the BSC showed growth of Gram-positive bacilli and the filamentous fungi of the Curvularia sp genus, which is considered a common 
environmental contaminant ${ }^{16}$. Bacteria and fungi are most often associated as biocontaminants that compromise indoor air quality ${ }^{17}$.

The results of a study conducted by Andrade Silva et al ${ }^{18}$ in an operating room of a hospital, using the same methodology as used in this study also showed the presence of filamentous fungi and other microorganisms.

The presence of these organisms suggests that the process of room and equipment cleaning is not adequate, or the entry and exit of individuals who work in these rooms are not being controlled. Studies conducted in Brazil emphasize the importance of restricting access to the handling area to trained personnel only to minimize particulate and microbial contamination ${ }^{19,20}$.

The contamination of handlers' gloves by microorganisms usually involve normal flora, coagulasenegative staphylococci and Klebsiella sp and highlights the role of the technician as a carrier of contamination ${ }^{21}$. In cases where contamination was detected on the handlers' gloves, it was observed that the hands were repeatedly removed from the cabinet during the manipulation process to obtain medicine bottles, syringes or other material; this did not occur with the other technicians. This procedure should be avoided because it can result in the introduction of contamination since the laminar flow is interrupted and microorganisms can be transferred from the gloves into the BSC $^{22}$. According to the American Society of Health-System Pharmacists, all materials necessary for aseptic preparation should be prepared in the critical area, i.e., inside the BSC to avoid interruption of the airflow between the HEPA filter and the critical placement of bottles and containers. This scenario is likely to have occurred because the samples from gloves before the handling process presented no microbiological growth, which confirmed their sterility ${ }^{12}$. Therefore, the validation of hand sterilization, education and training of the professional handler is extremely important for maintaining an aseptic area.

The major groups of air contaminant particles present in air-conditioned ambient conditions include fungi, bacteria, spores and viruses that originate from the outside air, air conditioning system, construction, furniture and especially from its occupants ${ }^{23}$. In this study, the contamination in the samples from the handlers' gloves was the same as the contamination found in the air conditioner samples, differing only in the number of CFU's (five coagulasenegative staphylococci colonies and one Klebsiella sp colony). Based on this methodology, the presence of contaminant fungi was not observed, perhaps as a result of the exposure time of this study. However, other studies have reported the frequency of bacterial contamination in clean hospital environments. Many studies have shown that assessing the level of contamination in areas considered at risk is very important in preventing infection ${ }^{24}$.

It is important to note that the physical space of the hospital chemotherapy pharmacy in this study does not conform to the RDC 220/04 and 50/02, which may contribute to contamination of the room air. In 2004, the Anvisa set the minimum requirements for the operation of the ATS in the Technical Regulation established by RDC 220/04. These include the requirements that the ATS should have a quality management system that is incorporated into GPPAT and an effectively documented and monitored quality control protocol. This system ensures the assessment and periodic registry of critical points in the process and implementation of corrective actions and continually improves the processes that ensure the quality of these products ${ }^{6,7}$.

This study was socialized among pharmacists of the Department of Oncology in the hospital in which changes in standard operating procedures had been immediately made, adopting mainly the presence of an assistant in the room for manipulation to avoid excessive removal of manipulator hand from inside the cabin and the disinfection of medicines and air conditioning of the clean room with $70 \%$ alcohol to minimize microbiological contamination. However, the validation of the procedures to guarantee the aseptic quality of the products is important.

\section{CONCLUSION}

In short, this study showed the environmental and process contamination, mainly by bacteria and fungi, which can be potentially pathogenic to immunocompromised individuals.

Our findings, in addition to those described by other authors and current laws, suggest the need for continuous monitoring of microbiological quality of processes, equipment and environmental preparation of chemotherapy agents, as well as a validation of the asepsis and the restructuring of physical space according to the RDC 50/02 and 220/04 to optimize therapy and minimize risks to public health.

Further studies are necessary to evaluate the final product and confirm contamination as a result of dubious and non-validated manipulation processes.

\section{FINANCIAL SUPPORT}

Project funded by grants from the Ministério da Educação, on the multiprofessional residency of health, linked to the HUJBB/UFPA. 


\section{Avaliação microbiológica do processo de manipulação de antineoplásicos em um hospital de referência no tratamento de câncer no Estado do Pará, Brasil RESUMO}

A Resolução RDC 220/04 da Agência Nacional de Vigilância Sanitária estabelece os requisitos mínimos para o funcionamento dos serviços de terapia antineoplásica e enfatiza a importância de um sistema de garantia da qualidade que abranja as melhores práticas para a preparação da terapia antineoplásica. De acordo com os protocolos farmacêuticos, os produtos devem obedecer às especificações determinadas pelas normas da legislação oficial. A qualidade microbiológica do ambiente na preparação das drogas antineoplásicas é um fator essencial para que seja realizada com eficiência e segurança. A segurança dos pacientes depende da esterilidade do produto, pois eles são geralmente imunocomprometidos. O objetivo deste estudo foi avaliar a qualidade microbiológica do processo de manipulação de drogas antineoplásicas em um hospital de referência no tratamento de câncer no Estado do Pará, Brasil. O material foi coletado da cabine de segurança biológica (CSB), de luvas de manipuladores e do sistema de ar-condicionado, por meio de swab de superfície e sedimentação espontânea. Os espécimes de bactéria e fungo foram identificados por procedimentos bioquímicos padrões, bem como por microcultura. Foram isoladas 31 unidades formadoras de colônias: 22 de amostras da CSB, seis do sistema de ar-condicionado e três de luvas de manipuladores. A maioria dos micro-organismos identificados nas amostras da CSB era de Staphylococcus e Bacillus sp. Foram encontrados Staphylococcus e Klebsiella sp nas luvas dos manipuladores e no sistema de ar-condicionado. Os resultados apresentados demonstraram uma contaminação microbiológica nos processos envolvidos na preparação de antineoplásicos. É necessário que se faça um monitoramento contínuo da qualidade microbiológica desses processos, dos equipamentos e do ambiente, e que seja feita a validação da assepsia e a reestruturação do espaço físico, para que sejam obedecidas as Resoluções RDC 50/02 e 220/04.

Palavras-chave: Antineoplásicos; Contaminação de Medicamentos; Boas Práticas de Manipulação; Staphylococcus; Bacillus; Klebsiella.

\section{Evaluación microbiológica del proceso de manipulación de antineoplásicos en un hospital de referencia en el tratamiento de cáncer en el Estado de Pará, Brasil \\ RESUMEN}

La Resolución RDC 220/04 de la Agência Nacional de Vigilância Sanitária establece los requisitos mínimos para el funcionamiento de los servicios de terapia antineoplásica y enfatiza la importancia de un sistema de garantía de la calidad que abarque las mejores prácticas para el preparo de la terapia antineoplásica. De acuerdo a los protocolos farmacéuticos, los productos deben obedecer a las especificaciones determinadas por las normas de la legislación oficial. La calidad microbiológica del ambiente en el preparo de las drogas antineoplásicas es un factor esencial para que éste sea realizado con eficiencia y seguridad. La seguridad de los pacientes depende de la esterilidad del producto, ya que son pacientes generalmente inmunocomprometidos. El objetivo de este estudio fue el de evaluar la calidad microbiológica del proceso de manipulación de drogas antineoplásicas en un hospital de referencia en el tratamiento del cáncer en el Estado de Pará, Brasil. El material se colectó de la cabina de seguridad biológica (CSB), de guantes de manipuladores y del sistema de aire acondicionado, por medio de swab de superficie y sedimentación espontánea. Los especímenes de bacteria y hongos fueron identificados por procedimientos bioquímicos estándar, bien como por microcultivo. Se aislaron 31 unidades formadoras de colonias: 22 de las muestras de la CSB, seis del sistema de aire acondicionado y tres de guantes de manipuladores. La mayoría de los microorganismos identificados en las muestras de la CSB era de Staphylococcus y Bacillus sp. Se hallaron Staphylococcus y Klebsiella sp en los guantes de manipuladores y en el sistema de aire acondicionado. Los resultados presentados demuestran una contaminación microbiológica en los procesos involucrados en el preparo de antineoplásicos. Es necesario realizar un monitoreo continuo de la calidad microbiológica de esos procesos, de los equipos y del ambiente, y que se valide la asepsia y la reestructura del espacio físico, para que se obedezcan las Resoluciones RDC 50/02 y 220/04.

Palabras clave: Agentes Antineoplásicos; Contaminación de Medicamentos; Buenas Prácticas de Manipulación; Staphylococcus; Bacillus; Klebsiella.

\section{REFERENCES}

1 Cleton FJ. Chemotherapy: general aspects. In: Peckham M, Pinedo HM, Veronesi H, editors. Oxford textbook of oncology. New York: Oxford University Press; 1995. vol. 1, p. 445-53.

2 Schneider PJ. Process validation. In: Buchanan EC, McKinnon BT, Scheckelhoff DJ, Schneider PJ, editors. Principles of sterile product preparation. Bethesda: American Society of Health-System Pharmacists; 1995. p. 121-4.
3 Yamamoto $\mathrm{CH}$, Pinto TJA, Meurer VM. Controle de qualidade microbiológico de produtos farmacêuticos, cosméticos e fototerápicos produzidos na Zona da Mata, Minas Gerais. Anais do $2{ }^{\circ}$ Congresso Brasileiro de Extensão Universitária; 2004 set 12-15; Belo Horizonte. Belo Horizonte: Universidade Federal de Minas Gerais; 2004 . p. 1-7.

4 Dalgo ML. Normatização farmacêutica em terapia nutricional. In: Waitzberg DL, editor. Nutrição oral, enteral e parenteral na prática clínica. 2. ed. São Paulo: Atheneu; 2002. p. 929-45. 
5 Krämer I, Wenchel HM. Viability of microorganisms in antineoplastic drug solutions. Eur J Hosp Pharm. 1991 Jun; 1:14-9.

6 Agência Nacional de Vigilância Sanitária (BR). Resolução RDC n ${ }^{\circ} 220$, de 21 de setembro de 2004. Aprova o regulamento técnico de funcionamento dos serviços de terapia antineoplásica. Diário Oficial da União. Brasília, 23 set. 2004.

7 Agência Nacional de Vigilância Sanitária (BR). Resolução RDC n 50, de 21 de fevereiro de 2002. Dispõe sobre o Regulamento Técnico para planejamento, programação, elaboração e avaliação de projetos físicos de estabelecimentos assistenciais de saúde. Diário Oficial da União, 20 mar. 2002.

8 Pasquarella C, Pitzurra $O$, Sarno A. The index of microbial air contamination. J Hosp Infect. 2000 Dec;46(4):241-56.

9 Morais GR, Silva MA, Carvalho MV, Santos JGS, Dolinger EJO, Brito DD. Qualidade do ar interno em uma instituição de ensino superior brasileira. Biosci J. 2010 mar-abr;26(2):305-10.

10 Pharmaceutical inspection convention. Pharmaceutical inspection co-operation scheme: guide to good manufacturing practice for medicinal products. Geneva: PIC/S; 2004. 143 p.

11 Koneman EW, Allen SD, Janda WM, Schreckenberger PC, Winn Jr WC. Diagnóstico microbiológico: texło e atlas colorido. São Paulo: Medsi; 2001. 1465 p.

12 Koneman EW, Allen SD, Janda WM, Schreckenberger PC, Winn Jr WC. Diagnóstico microbiológico: texło e atlas colorido. 6. ed. São Paulo: Guanabara Koogan; 2008. $1468 \mathrm{p}$.

13 European good manufacturing practices. Guide to manufacture of sterile medicinal products; 1997.

14 Neder RN. Microbiologia: manual de laboratório. São Paulo: Nobel; 1992. p. 25-6.

15 ASHP guidelines on quality assurance for pharmacyprepared sterile products. Am J Health Syst Pharm. 2000 Jun;57(12):1150-69.
16 Zanon U. Riscos infecciosos imputados ao lixo hospitalar: realidade epidemiológica ou ficção sanitária? Rev Soc Bras Med Trop. 1990 julset;23(3): 163-70.

17 Gontijo Filho PP, Silva CRM, Kritski AL. Ambientes climatizados, portaria 3.523 de 28/8/98 do Ministério da Saúde e padrões de qualidade do ar de interiores do Brasil. J Bras Pneumol. 2000 setout;26(5):254-8.

18 Andrade SI, Gontiio Filho PP, Melo GB. Análise microbiológica quantitativa e qualitativa do ar do centro cirúrgico durante realização de cirurgias cardíacas no hospital de clínicas da Universidade Federal de Uberlândia. Hor Ci. 2010;3(2): 1-19.

19 Maravich MD, Morgan B. Alkylating Agents. In: Kirkwood JM, Lotze MT, Yasko JM, editors. Current Cancer Therapeutics. 2. ed. Churchill Livingstone; 1996. p. 1-36.

20 Polliack A. A handbook of essential drugs and regimens in hematological oncology. Chur: Harwood Academic Publishers; 1991. $180 \mathrm{p}$.

21 Pratt RJ, Pellowe CM, Wilson JA, Loveday HP, Haper PJ, Jones SRLJ, et al. Epic2: national evidence-based guidelines for preventing healthcare-associated infections in NHS hospitals in England. J Hosp Infect. 2007 Feb;65 Suppl 1:S1-64.

22 Flores A. Appropriate glove use in the prevention of cross-infection. Nurs Stand. 2007 May;21 (35):45-8.

23 World Health Organization. Indoor air quality: biological contaminants, report on a WHO meeting, Rautavaara, 29 August - 2 September 1988. Copenhagen: WHO Regional Office for Europe; 1990.67p.

24 Wanner H-U, Verhoeff A, Colombi A, Flannigan B, Gravesen S, Mouilleseaux A, et al. European collaborative action: environment \& quality of life indoor air quality and its impact on man. Luxembourg: Office for Official Publications of the European Communities; 1993.81 p. (Environment and quality of life, Report No. 12: Biological particles in indoor). 